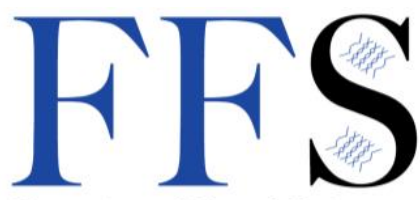

Functional Food Science

\title{
Vitamin D fortification: A perspective to improve immunity for COVID-19 infection
}

\author{
Sheetal Handu ${ }^{1}$, Shumaila Jan ${ }^{1}, K_{\text {Komal Chauhan }}{ }^{\text {and D.C. Saxena }}{ }^{2}$
}

${ }^{1}$ Department of Food Science and Technology, National Institute of Food Technology, Entrepreneurship and Management, Sonipat, Haryana, India 2Department of Food Engineering and Technology Sant Longowal Institute of Engineering and Technology, Longowal, Punjab, India

*Corresponding Author: D.C. Saxena, PhD, Department of Food Engineering and Technology Sant Longowal Institute of Engineering and Technology, Longowal, Punjab, India

Submission Date: September 10 th, 2021 ; Acceptance Date: October 24th, 2021 ; Publication Date: October $27^{\text {th }}, 2021$

Please cite this as: Handu S., Jan S., Chauhan K., Saxena D.C. Vitamin D fortification: A perspective to improve immunity for COVID-19 infection. Functional Food Science 2021. 1(10): 50-66. DOI: https://www.doi.org/10.31989/ffs.v1i10.843

\section{ABSTRACT}

The need for food fortification arises because of the close relationship between humans, health, and food. The problem of the prevalence of micronutrient malnutrition paved a way for food fortification to emerge and run in this technological era. This review focuses on the importance of vitamin $D$ in the present pandemic situation and the techniques used for fortification. Stability and bio-accessibility are the biggest question in the food fortification process as a large proportion of vitamin $D$ is lost during food processing and storage due to environmental stress conditions such as temperature, $\mathrm{pH}$, salt, oxygen, and light. Vitamin $\mathrm{D}$ is an important micronutrient required for the prevention of respiratory disorders, neurodegenerative diseases, cardiovascular diseases, cancer etc. which make it essential in enhancing immunity against COVID-19. Food fortification is the most efficient and safest method recognized by the WHO. The present review is an update on vitamin $D$, considering its role and importance and fortification techniques adopted. Among all the techniques, nanoencapsulation is found to be an efficient one with the increasing demand. 


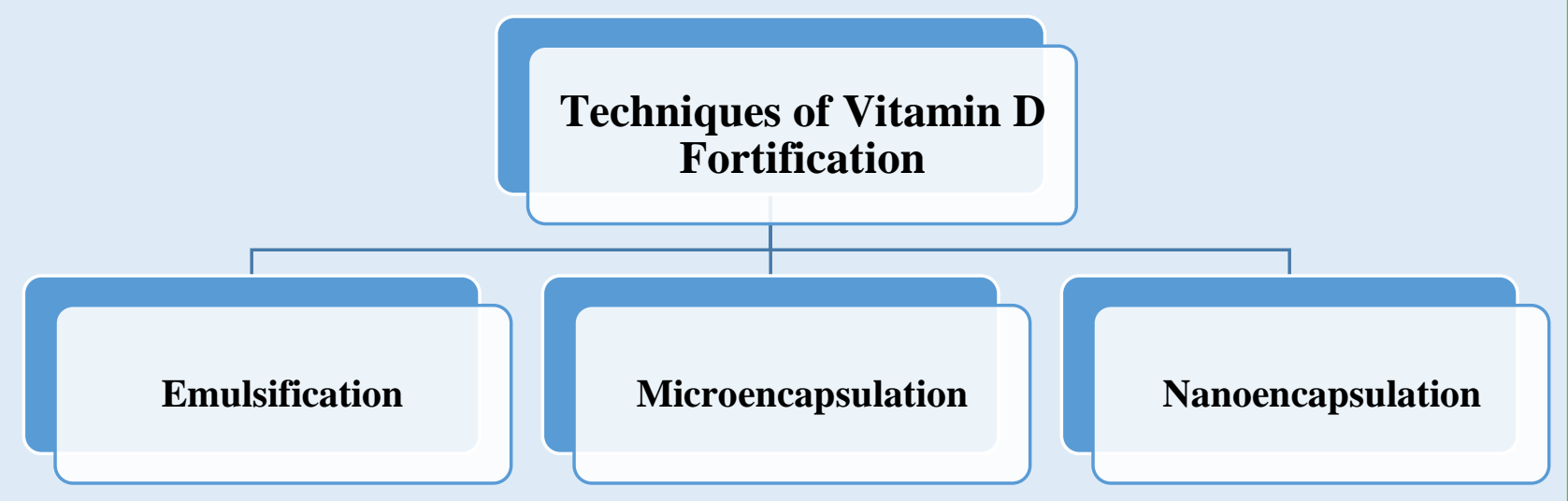

CFFC 2021. This is an Open Access article distributed under the terms of the Creative Commons Attribution 4.0 License (http://creativecommons.org/licenses/by/4.0)

\section{INTRODUCTION}

Health claims are becoming increasingly significant, and there is widespread agreement that a regulatory framework is required to protect consumers, promote fair trade, and stimulate product innovation in the food sector. Asia has the world's highest proportion of micronutrient-deficient people, and chronic malnutrition is putting millions of babies and fetuses at risk of birth abnormalities, stunted development, and a high death rate. According to research, over 2 billion individuals worldwide suffer from important trace micronutrient insufficiency, which is mostly caused by a lack of vitamins and minerals in their diet [1]. These inadequacies (sometimes referred to as "hidden hunger") of micronutrients are due to poor micronutrient bioavailability and an imbalanced diet [2]. Vitamin D is a steroid hormone that is produced endogenously by the skin's response to ultraviolet radiation or obtained from exogenous food sources or dietary supplements, such as cod liver oil and fatty fish (e.g. salmon, mackerel, and tuna), UV-irradiated mushrooms, fortified foods, and supplements [3]. Vitamin $D$ comes in two forms: vitamin D2 (ergocalciferol) and vitamin D3 (cholecalciferol). Vitamin D2 (ergocalciferol) is mostly human-made and added to meals, whereas vitamin D3 (cholecalciferol) is produced in human skin from 7-dehydrocholesterol and absorbed in the diet through animal-based foods. Vitamin $D$ is a steroid hormone, produced endogenously with the effect of ultraviolet radiation on the skin or available from exogenous food sources or dietary supplements, including cod liver oil and fatty fish (e.g., salmon, mackerel, and tuna); UV-irradiated mushrooms; foods fortified with vitamin D; and supplements [3]. Vitamin D is present majorly in two forms, in example, vitamin D2 (ergocalciferol) and vitamin D3 (cholecalciferol). Vitamin $D_{2}$ (ergocalciferol) is largely human-made and added to foods, whereas vitamin $D_{3}$ (cholecalciferol) is synthesized in the skin of humans from 7-dehydrocholesterol and is also consumed in the diet via the intake of animal-based foods. Both vitamin $D_{3}$ and vitamin $D_{2}$ differ only in their side-chain structure. The differences do not affect metabolism (i.e., activation), and both forms function as prohormones [4]. Vitamin D (D2, D3, or both) deficiency is an international health concern that has 
been associated with rickets osteomalacia, muscle weakness, osteoporosis and an increased risk of wheezing diseases, autoimmune diseases (e.g., type 1 diabetes, multiple sclerosis, rheumatoid arthritis, and Crohn's disease), and cancer, such as of the prostate, breast, and colon [5]. Inadequate vitamin D exposure can cause calcium and phosphorus absorption to be decreased, which can lead to bone mineralization [4]. The mortality reports of WHO showed that vitamin D deficiency is one of the major contributors to total deaths (0.8 million deaths) per annum [1]. In the past few decades, awareness that vitamin $D$ deficiency is a serious public health problem in many developing countries has increased. Although standards vary, most experts agree that levels of $25(\mathrm{OH}) \mathrm{D}$, a biomarker for vitamin D, below $20 \mathrm{ng} / \mathrm{ml}$ (nanograms per milliliter) reflect clear-cut vitamin D inadequacy, while levels between 20 and $30 \mathrm{ng} / \mathrm{ml}$ are borderline. Vitamin D's best-known role is to keep bones healthy by increasing the intestinal absorption of calcium. In industrialized countries, it is estimated that more than $30-50 \%$ of both children and adults from at least one of the manifestations of vitamin D deficiency. Vitamin D deficiency prevails in epidemic proportions in developing countries for example in India its prevalence is $70 \%-100 \%$ in the general population [6].

Food Fortification: A better solution: Various technologies are being adopted by the food industries to combat the challenge faced by food industries. One of these technologies includes fortification of food which is a promising strategy for reducing the prevalence of micronutrient deficiency. Food Fortification is generally adding nutrients to food in insignificant amounts, either present already or absent. This even includes additions fulfilling the role of another food in the diet [7]. Fortification of food products has been acknowledged as the most costeffective way for combating nutrient deficiency problems among the available health interventions [8]. India is home to a 1:3 ratio of the world's foodless youngsters and has the second-highest level of wasting among youngsters globally. These high levels of hunger are due partly to poor food quality that lacks vital micronutrients that are units necessary for growth and development. Food vehicles must be designed considering their synergistic effects with micronutrients for effective absorption and bioavailability. However, the scalability, bioaccessibility, cost economics, safety concerns and acceptability of the micronutrient fortified foods remain as constraints that should be addressed. One of the major requirements of food fortification is the proper identification and suitability of a food vehicle. Essentially the vehicle should be such food that is commonly consumed by the target population to get high bioavailability/bio-accessibility of micronutrients [9]. Cereals and flour as a staple food are more commonly used as food vehicles for fortification. In conjunction, an estimate showed that the amount of fortification of flour was found to be $97 \%$ in the US, $25 \%$ in Asia, $6 \%$ in Europe, $31 \%$ in Africa, $44 \%$ in Mediterranean countries and 4\% in Pacific regions [10]. In addition to this, pulses also hold an important part of Indian diets, and fortification of micronutrients in milled dhal and its flour would be a cheaper vehicle for micronutrient delivery. A few countries have adopted mandatory or voluntary fortification of cereal flours with vitamin $A$, iron, zinc, thiamine, riboflavin, folic acid, niacin, and vitamin B12, but this practice is practically insufficient to meet the nutritional requirements of nutritionally vulnerable populations. 
Many techniques and technologies are used to fortify many food vehicles to increase the nutrients in the food. But few technologies are insufficient to maintain all the physiological properties of the food vehicle after fortification and day by day the bioavailability of nutrients are becoming less. With recent technologies, including bio-fortification and nano-food fortification are explained how it helps improve the efficiency of fortifications day by day. These led to detailed searching for evidence of food fortification and recently developed technologies to fortify those micronutrients in foods.

Various Fortificants and their Food Vehicles: The fortification technology used depends on the selection of appropriate food vehicles and fortificant which should meet the need of specific fortification like alleviating disease or elucidating prophylaxis of a deficiency. The technological advances from mixing of a fortificant to biofortification of crops have been studied. The various methods of fortification studied include mixing of an ingredient, dissolution in water and in oil, encapsulation through spray drying, spray cooling, fluidized bed coating, nanoencapsulation of minerals and biofortification of crops [11]. There has been an advance in efficiency of mixing based technologies such as dry mixing, spray mixing, drip addition using various types of mixers like ribbon blender and drum mixer. The use of spray drying among other methods for encapsulation of micronutrient proved to be an economic and efficient technology even with some disadvantages. An efficient way for delivering two or more micronutrients simultaneously in a stable and bioavailable form without interaction is by microencapsulation of nutrients in an inert but digestible matrix, separating them from other food components and other micronutrients added to food. Nanoencapsulation is gaining popularity to fortify foods with respect to bioavailability [12]. Biofortification of crops in recent years through genetic engineering and conventional breeding has caught the attention of the industry and may be a permanent solution for prophylaxis of micronutrient malnutrition [13]. Different techniques used for the fortification are mentioned in Table 1. Various fortificants and the food vehicles used for fortification are mentioned below:

- Iron: Iron deficiency is one of the most common nutritional problems worldwide and insufficient iron bioavailability leads to anemia. Iron fortification through addition of NaFeEDTA (Ferric Sodium Ethylene Diamine tetraacetate); ferrous biglycinate; ferrous fumarate; ferric pyrophosphate foods and flours of cereals and pulses provides sufficient level of iron [14].

- lodine: lodine is an important component of thyroid hormones, thyroxine, and triiodothyronine and it is utilized by the thyroid glands to make thyroid hormones that control many functions in the body including growth and development. Deficiency of iodine in young children and pregnant women causes goiter. Fortification forms of iodine are potassium (K) salts such as potassium iodide (KI) and potassium iodate (KIO3) [15] which are fortified through biofortification of crops [16] and spray dry techniques in salt and other flour items [17].

- Calcium: Calcium is an important micronutrient that is rich in dairy foods such as milk and cheese. It is helpful in maintaining the metabolism and keeping the bone healthy, on contrary lower intake of calcium can lead to rickets in children and 
osteomalacia in adults. Calcium in the form of calcium salt such as calcium carbonate, calcium chloride, and calcium citrate are used as fortificants [18]. Some of the foods fortified with calcium include fruit and juice beverages, cereals, and snack bars [19].

- Vitamin A: Vitamin A is an important micronutrient used to cure night blindness, supports the immune system, and lowers the risk of cancer. Vitamin A is fortified with food such as cookies and pasta with vitamin A fortificant retinyl acetate [20]. Some of the foods fortified with vitamin A include edible oils and fats, condiments, refined sugar [21].

- Dietary Fibers: Fiber is important nutrients which help in constipation problems. Long-term constipation has serious health problems. Food fibers can be classified into two types which are soluble and insoluble fibers. There are more medical advantages in strands including keeping up with intestinal, controlling glucose levels, controlling glucose level. Fortification form of fibers are plant sources such as guar gum is used to fortify yogurt [22], noodles [23] and inulin can be used in processed meat products such as sausages [24].

- Zinc: Zinc is the essential nutrient required for growth, immune system, and pregnancy. It helps in the development of children with stunted growth and diseases such as diarrhea and pneumonia. The most common fortificants used for zinc are zinc oxide and zinc sulfate [25]. The study of biofortification of zinc to bread wheat grain focused on three different methods: soil application, seed priming, foliar spraying for biofortification of crops. The addition of zinc to bread wheat grain through methods mentioned increased the grain zinc concentration of wheat [26].

\section{Current Vitamin D Fortification Status: Fortification} programs for vitamin $\mathrm{D}$ have been implemented in the world. Fortification of vitamin D depends on the availability and consumption pattern of food in the population of a country. Mainly food fortified with vitamin D includes milk, dairy products, edible oil, and fruit juices. Since vitamin $D$ is a fat-soluble vitamin, it is also fortified with other fat-soluble vitamins such as vitamin A [27]. Many countries have reported successful fortification programs for vitamin $D$ and further adopted regulatory compliance for vitamin D fortified food. It has become mandatory by the Canadian Food and Drug Regulations to fortify milk (except goat milk and condensed milk) and margarine [28]. In the USA, food fortified with vitamin D has to be displayed on the labels [29]. In some countries such as the UK and Ireland, it is voluntary to fortify margarine manufactured for domestic use [30]. Globally, all infants up to 1 year of age should receive a daily dose of $400 \mathrm{IU} /$ day $(10 \mu \mathrm{g})$ of vitamin D [31]. The recommended dietary intake for children and adolescents (up to 18 years of age) of vitamin D is 600 IU/day [32]. Fortification of vitamin D for infants were found in the following products: Cereal based baby porridge, soy milk, infant milk, follow-on formula, infant formula, yogurt drink, instant chocolate milk, curd cheese dessert and fruit juices [33]. In the world, food products that are being fortified with different levels of vitamin D are listed in Table 2. Some food products such as dried and evaporated milk, breakfast cereals, macaroni, noodles, beverages, edible oils, and wheat flour are also fortified with vitamin $D$ along with other micronutrients. However, there is a challenge in 
managing the continuation and compliance of the regulations for fortification. Also, the key concern for food processors is to study the stability, dispensability, and solubility of vitamin D during the production and storage of foods [34].

Role of Vitamin D in COVID-19: Vitamin D deficiency is a worldwide public health issue that affects more than a billion individuals of all age groups [35]. Several studies in the last decade have found a link between vitamin D deficiency and a variety of disorders, including systemic infection. [36-38]. Vitamin D deficiency has an impact on immune functioning because it acts as an immunomodulator [39], boosting innate immunity through the production of antiviral peptides [40], which increases mucosal defenses. In clinical investigations, low levels of serum vitamin D have been linked to acute respiratory tract infections, particularly epidemic influenza [41-42]. According to a recent meta-analysis that included data from eight observational studies, persons with a blood vitamin D content of less than $50 \mathrm{nmol} / \mathrm{l}$ (i.e., less than $20 \mathrm{ng} / \mathrm{ml}$ ) had a $64 \%$ increased risk of community-acquired pneumonia [43]. Some recent reviews hypothesized that insufficient vitamin $D$ may damage the immune function of the respiratory tract, increasing the severity of COVID-19 and the risk of death [44-45]. Some retrospective studies have determined the correlation between vitamin $D$ levels and the severity and mortality of COVID-19 [46-50]. The outbreak and rapid spreading of SARS-CoV-2 is a global health threat with an uncertain outcome in the world. Recent data reported the antiviral effects of vitamin $D$, which has been shown to hinder viral replication directly, as well as has anti-inflammatory and immunomodulatory properties [51]. It seems that SARS-CoV-2 predominantly uses the immune evasion process during infection, followed by hyper reaction and cytokine storm in some patients [52], which is a known pathogenic pathway in the development of acute respiratory disease syndrome (ARDS) [53]. SARS-CoV-2 enters alveolar and intestinal epithelial cells via using angiotensin-converting enzyme 2 as the host receptor [54]. Subsequent dysregulation of the reninangiotensin system may lead to excessive cytokine production resulting in potentially fatal ARDS [53].

Bioaccessibility and Stability of Vitamin D: Today, as per the latest medical reports available, much of the population throughout the globe is facing vitamin D deficiency. Other than the sunlight, there are very limited sources of vitamin D to fulfil the recommended dietary allowance of vitamin D (RDA: 400-800 IU per day) [55]. A large proportion of vitamin D is lost during food processing and storage due to environmental stress conditions such as temperature, $\mathrm{pH}$, salt, oxygen, and light. Vitamin D deficiency can be corrected and prevented by sun exposure, increasing the dietary intake of vitamin $D$ and reducing the underlying factors that hinder adequate absorption and utilization [56]. Periodic distribution of high dose vitamin $D$ supplements seems to be an alternative option. However, its sustainability is questionable for many reasons: (i) gradual loss of interest by the target population (ii) difficult to ensure a continuous and adequate supply of the supplements and maintain an efficient distribution system [57]. To meet the RDA requirements for vitamin $D$, several countries have now permitted fortification of food with vitamin D such as milk, edible oils, cereals etc. In addition to this, currently, certain pharmaceutical supplements are also majorly being used as the source of vitamin D [58]. 
Despite the availability of vitamin D fortified food, vitamin D deficiency is prevailing across the globe which could be attributed to the low bioavailability of vitamin D (fortified as well as naturally occurring foods) in the food as well as in the human gastrointestinal tract (GIT) [59]. According to a research report published by the FAO, extended storage of vitamin Afortified flour under severe conditions such as high temperature and improper packaging leads to an $85 \%$ loss in vitamin A activity within 3 months of storage [60]. Even with food fortification, intake of vitamin D is inadequate to obtain and maintain target $25(\mathrm{OH}) \mathrm{D}$ concentration of at least $30 \mathrm{ng} / \mathrm{mL}(75 \mathrm{nmol} / \mathrm{L})$, and some of the modes used to generate fortified food do not reach those who need them (e.g., rice) [61]. Though several pharmaceutical formulations have been introduced to correct the imbalance, these formulations do not become healthy alternatives due to cost associated, out of reach to the public and their psychological impact as well as their adverse effect on health. Vitamin D is a fat-soluble vitamin, and its stability is determined by the fat medium in the fortified diet. Due to the volatility and varied dispersion of vitamin $D$ in food, its fortification poses a significant problem to the food industry. Foods supplemented with vitamin D, such as milk, cheese, and yogurt, have been found to have lower vitamin $D$ retention [62]. Food processing methods such as baking, cooking, frying, and boiling degrade vitamin $D$ significantly. There are very few studies on the stability and uniform distribution of vitamin D fortified meals [63].

Technologies used for Vitamin D fortification: For the fortification of vitamin $D$, there are various techniques which include emulsification, microencapsulation, and nanoencapsulation. Direct addition of vitamin $D$ is mainly adopted for milk and milk products [46]. In this method, vitamin D is dissolved in food-grade organic solvent (ethanol) and butter oil and then homogenized into the food matrix to ensure the uniform distribution in milk [64-65]. It has been found that there is a deposition of vitamin $\mathrm{D}$ inside the packaging materials especially the poly packs or tetra packs and degradation in the aqueous food matrix led to instability of vitamin $D$ in the food matrix. In the emulsification method, vitamin D acts as a water phase and is dispersed in the oil phase as fine droplets and then mixed with food products such as cheese, milk, and bread [66-67]. The major challenges found in the fortification of vitamin $D$ by the emulsification method is the availability of food-grade emulsifiers and the development of stable emulsion in the food matrix. Dispersibility, homogeneity, stability are a few challenges that affect the vitamin $D$ bioavailability to the body. Various innovative techniques came up with time which includes microencapsulation through nanotechnology. This method offers better stability and homogeneity by encapsulating the bioactive material in the food matrix at less than $1000 \mathrm{~nm}$ size. According to the literature, fortification using nanoparticles has several advantages over direct addition and emulsification methods, including increased stability, homogeneity, and improved physicochemical and organoleptic properties [68].

Nanoencapsulation Technique: Nanoencapsulation is the entrapment of bioactive compounds within a nanoscale carrier and is considered as an appropriate technology to overcome the bioavailability or bio accessibility of the bioactive compound. This technique increases bioactive solubility, enhances release 
behavior, cellular uptake, and bioavailability [69-73]. The selection of appropriate shells and methods for nanoencapsulation is an important and interesting field of research. The applied shell for entrapment of food bioactive should meet some criteria such as biocompatibility and biodegradability. Abundantly available starch is one of the good candidates to produce nano-delivery systems. It causes slow-release, inhibition of inadvertent release, reducing probable complications due to overdose and more effectiveness of sensitive ingredients [74-76]. The starch structure is known as a "double helix" [77] that consists of two types of molecules: the linear and helical amylose and the branched amylopectin [78]. The natural and spontaneous tendency of amylose to form single helical molecular inclusion complexes is termed $\mathrm{V}$ amylose [79-82]. It has a central hydrophobic cavity interconnected by amorphous regions of the polysaccharide chains which render the complexes stable to acidic hydrolysis and may be used as a possible platform for the encapsulation of hydrophobic molecules [83-86]. The technology used for food fortification include nanosuspensions, nanoliposomes, nano emulsions, and cyclodextrin carriers. The coating materials used for encapsulation of fortificants includes starches, sugars, fats, gums, chitosan, gelatin, and maltodextrin [87]. The application and their complexes are developed using surfactants, clinkers, and chelating agents. Nanoencapsulation of fortificants can be done by two methods i.e., electro spinning (fiber-like fortificants) and electro-spraying (particlelike fortificants) [88]. Further, the technique of nanoencapsulation does not contribute significant changes in the physicochemical properties and rheological properties of fortified foods. Nanotechnology-based techniques are also helpful in addressing challenges that include encapsulating hydrophobic fortificants into food [89].

Microencapsulation Technique: Microencapsulation is basically insulation of bioactive core material by secondary wall materials which protect the core from its external environment [90-92]. In addition to giving protection to the bioactive compound, it also helps in the controlled release of the encapsulant. Microencapsulation also promises that the nanomaterials so formed would ensure high bioavailability, water dispersibility and better homogeneity of the fortificant in the target food irrespective of the complexity of the food matrix [69]. It aids in the regulated release of encapsulants with great physicochemical stability, as well as protecting the bioactive component [90-92]. Microencapsulation additionally guarantees, regardless of the complexity of the food material [69]. It is an efficient way for delivering two or more micronutrients simultaneously in a stable and bioavailable form without interaction is by microencapsulation of nutrients in an inert but digestible matrix, separating them from other food components and other micronutrients added to food [93]. The benefits of microencapsulation of vitamin D in food products include blocking the passage for vitamin $D$ into the food matrix; protects against environmental conditions such as moisture, oxidation, $\mathrm{pH}$, temperature; ensures higher bioavailability by releasing encapsulated vitamin $D$ in a regulated and targeted manner; does not affect the appearance, taste, and quality of the food matrix, thus maintains customer acceptability [94]. Microencapsulation can be done by using spray drying. This is one of the oldest techniques used for bioactive compounds encapsulation [95]. Spray drying involves the 
dissolution of wall material and core material resulting in the formation of emulsion, followed by the process of homogenization, pumping of emulsion, atomization of emulsion and subsequent dehydration of the atomized droplets to yield microcapsule [96]. Vitamin $D$ is needed to be homogenized in a dispersion containing wall materials (polymers). Then, the homogenized dispersion needs to be fed to the spray dryer and atomized by hot air that leads to the development of nanomaterials in consequence of water evaporation [97-100]. The encapsulation process is subjected to a range of factors like homogeneity of dispersion system, quantity, quality, and type of emulsifier used, feed rate, viscosity of dispersion system, pressure of hot air, the flow rate of hot air and inlet and outlet temperature [101-104].
Emulsification technique: Another technique used for fortification of food can be emulsification. It involves at least two immiscible phases (lipid and water) where one phase needs to be dispersed as small spherical droplets within another phase. Two types of emulsions, oil in water (O/W) or water in oil (W/O) are classified based on their spatial arrangement of two phases. These two immiscible phases need to be stabilized by surfactants and emulsifiers [105]. Several techniques of emulsions to develop vitamin D-nanomaterials using food-grade materials such as whey protein isolate (WPI) [106], casein [107], Medium-chain triglycerides (MCT), Zein and carboxymethyl chitosan [108], Tween 20 and casein [109], have been explored. The selection of emulsion methods for vitamin $D$ encapsulation depends on various factors such as absence/presence of antioxidants, quantity, type of carrier oils, and surfactant.

Table 1: Different techniques used for the fortification in various food vehicles

\begin{tabular}{|c|c|c|c|c|}
\hline Technology & Method & Fortificants & Food Vehicles & References \\
\hline \multirow[t]{2}{*}{ Mixing } & Dry Mixing & Iron & Fish Sauce & {$[110]$} \\
\hline & Ribbon Blender & Iron and lodine & Edible Salt & {$[111]$} \\
\hline \multirow[t]{6}{*}{ Biofortification } & Fertigation & lodine & Spinach & [16] \\
\hline & Foliar Spraying & lodine & Potato, tomato & {$[112]$} \\
\hline & Breeding & Vitamin A & Sweet Potato, Banana & {$[113]$} \\
\hline & Breeding & Iron & Rice & {$[114]$} \\
\hline & $\begin{array}{l}\text { Soil Application and Seed } \\
\text { Priming }\end{array}$ & Zinc & Wheat grain & {$[26]$} \\
\hline & Transgenic & Iron & Rice, Potato & [115-116] \\
\hline \multirow[t]{4}{*}{ Microencapsulation } & Spray Drying & lodine & Edible Salt & {$[17]$} \\
\hline & Extrusion & Minerals & $\begin{array}{l}\text { Rice Kernels, Corn Based } \\
\text { Snacks }\end{array}$ & [117] \\
\hline & Spray Chilling & $\begin{array}{l}\text { lodine, Iron and } \\
\text { Vitamin A }\end{array}$ & Edible Salt & [118] \\
\hline & Coating & Calcium & Soy-milk & [119] \\
\hline \multirow[t]{2}{*}{ Nanoencapsulation } & Electrospinning & Iron & Yogurt, Biscuits & {$[120]$} \\
\hline & Nanoliposome entrapment & $\omega-3$ PUFAs & Yogurt & {$[121]$} \\
\hline
\end{tabular}


Table 2: Vitamin D fortification level of different food groups in the world

\begin{tabular}{|c|c|c|c|}
\hline Country & Food Name & $\begin{array}{l}\text { Vitamin D fortification level for } \\
\text { adults }\end{array}$ & References \\
\hline \multirow{10}{*}{$\begin{array}{l}\text { United States } \\
\text { America }\end{array}$} & Milk & $400 \mathrm{IU} / 946 \mathrm{ml}$ & \multirow[t]{10}{*}[29,122-123]{} \\
\hline & Yogurt & $89 \mathrm{IU} / 100 \mathrm{~g}$ & \\
\hline & Margarine & $89 \mathrm{lU} / 100 \mathrm{~g}$ & \\
\hline & Cheese and cheese products & $81 \mathrm{IU} / 30 \mathrm{~g}$ & \\
\hline & Enriched rice & $550-2200 \mathrm{IU} / \mathrm{kg}$ & \\
\hline & Breakfast cereals & $350 \mathrm{IU} / 100 \mathrm{~g}$ & \\
\hline & Enriched noodle & $90 \mathrm{IU} / 100 \mathrm{~g}$ & \\
\hline & Orange juice & $100 \mathrm{IU} / 240 \mathrm{ml}$ & \\
\hline & Malted Drink & $123 \mathrm{IU} / \mathrm{g}$ & \\
\hline & Soy Based Drink & $140 \mathrm{IU} / 240 \mathrm{ml}$ & \\
\hline \multirow[t]{3}{*}{ Canada } & Milk & $300-400 \mathrm{IU} / 100 \mathrm{~g}$ & \multirow[t]{3}{*}{ [124-125] } \\
\hline & Infant formulas & $530 \mathrm{IU} / 100 \mathrm{~g}$ & \\
\hline & Meal replacements and supplements & $300-400 \mathrm{IU} / 100 \mathrm{~g}$ & \\
\hline \multirow[t]{2}{*}{ Australia } & Fat spreads & $220-640 \mathrm{IU} / 100 \mathrm{~g}$ & \multirow[t]{2}{*}{ [126] } \\
\hline & Breakfast cereals & $100 \mathrm{IU} /$ serving & \\
\hline \multirow[t]{3}{*}{ United Kingdom } & Margarine & $282-352.8 \mathrm{IU} / 100 \mathrm{~g}$ & \multirow[t]{3}{*}{ [127] } \\
\hline & Bread & $200 \mathrm{IU} / 100 \mathrm{~g}$ & \\
\hline & Orange Juices & $1000 \mathrm{IU} / 240 \mathrm{ml}$ & \\
\hline \multirow[t]{3}{*}{ India } & Milk & $200-300 \mathrm{IU} / \mathrm{L}$ & \multirow[t]{3}{*}{ [128] } \\
\hline & Vanaspati & $44 \mathrm{IU}-64 \mathrm{IU} / 100 \mathrm{~g}$ & \\
\hline & Edible oil & $44 \mathrm{IU}-64 \mathrm{IU} / 100 \mathrm{~g}$ & \\
\hline \multirow[t]{3}{*}{ Malaysia } & Condensed milk & $111 \mathrm{IU} / 100 \mathrm{~g}$ & \multirow[t]{3}{*}{ [129] } \\
\hline & Bread & $83 \mathrm{IU} / 100 \mathrm{~g}$ & \\
\hline & Breakfast cereals & $333 \mathrm{IU} / 100 \mathrm{~g}$ & \\
\hline \multirow[t]{2}{*}{ Philippines } & Milk & $\geq 9731 \mathrm{U} / \mathrm{L}$ & \multirow[t]{2}{*}{ [130] } \\
\hline & Margarine & $3300 \mathrm{IU} / \mathrm{kg}$ & \\
\hline Brazil & Dried skimmed milk & $2000-2400 \mathrm{IU} / \mathrm{kg}$ & [131] \\
\hline
\end{tabular}

\section{CONCLUSION}

Vitamin $D$ is important for the proper functioning of the immune system. The outbreak of the COVID 19 pandemic had a massive impact on the health and economy of the world. The pandemic has made people more concerned about their health and fitness. Vitamin D deficiency is very common in all age groups of humans which are mainly associated with viral respiratory tract infections. However, fortification is considered the most effective way to improve the uptake and availability of vitamin D. This review paper discusses the various techniques such as emulsification, microencapsulation and nanoencapsulation used for fortification of vitamin $D$. Encapsulation of vitamin $D$ protects against degradation before it reaches the target site in the body.

Microencapsulation provides desired functionality such as stability and homogeneity and overall better bioavailability of vitamin $D$. Nanoencapsulation is the latest technique used for fortification of vitamin D by maintaining stability during 
thermal processing and storage. There is certainly wide scope to develop novel techniques for fortification of vitamin D with better stability and availability.

List of Abbreviations: ARDS: Acute Respiratory Disease Syndrome, WHO: World Health Organization, COVID: Corona Virus Disease 2019, UV: Ultraviolet, SARS-CoV2: Severe Acute Respiratory Syndrome Coronavirus 2, USA: United States of America, UK: United Kingdom, IU: International Unit, RDA: Recommended Dietary Allowance, GIT: Gastro-Intestinal Tract, FAO: Food and Agriculture Organization, WPI: Whey Protein Isolate, MCT: Medium Chain Triglycerides.

\section{REFERENCES}

1. World Health Organization. Global nutrition targets 2025: Stunting policy brief. World Health Organization; 2014. https://apps.who.int/iris/bitstream/handle/10665/14901 9/WHO N? sequence $=1$

2. Haq A, Wimalawansa SJ, Pludowski P, Al Anouti F. Clinical practice guidelines for vitamin $D$ in the United Arab Emirates. The Journal of Steroid Biochemistry and Molecular Biology. 2018, 175:4-11. https://doi.org/10.1016/j.jsbmb.2016.09.021

3. Smit E, Crespo CJ, Michael Y, Ramirez-Marrero FA, Brodowicz GR, Bartlett S, Andersen RE. The effect of vitamin $D$ and frailty on mortality among noninstitutionalized US older adults. European Journal of Clinical Nutrition. 2012, 66(9):1024-8. https://doi.org/ $\underline{10.1038 / \text { ejen.2012.67 }}$

4. Ross AC, McComsey GA. The role of vitamin D deficiency in the pathogenesis of osteoporosis and in the modulation of the immune system in HIV-infected patients. Clinical Reviews in Bone and Mineral Metabolism. 2012, 10(4):27787. https://doi.org/ 10.1007/s12018-012-9131-0

5. Biancuzzo RM, Young A, Bibuld D, Cai MH, Winter MR, Klein EK, et al. Fortification of orange juice with vitamin D2 or vitamin D3 is as effective as an oral supplement in maintaining vitamin D status in adults. The American Journal of Clinical Nutrition. 2010, 91(6):1621-6. https://doi.org/ 10.3945/ajcn.2009.27972

6. Harinarayan CV, Joshi SR. Vitamin D status in India-its implications and remedial measures. JAPI. 2009, 57:40-8. https://doi.org/10.1.1.456.6667\&rep=rep1\&type=pdf
Authors' Contribution: SH, SJ, KC and DCS are all the contributors to this review article. SJ, KC and DCS conceptualized the review article. SH and SJ curated data and drafted the manuscript. KC and DCS reviewed and edited the manuscript. All authors read and approved the final manuscript.

Competing Interests: The authors declare no competing interests.

Acknowledgements: Authors would like to acknowledge the National Institute of Food Technology Entrepreneurship and Management (NIFTEM) for financial support. Authors would also like to acknowledge SEED project money for financial support.

7. Ottaway PB. Principles of food fortification and supplementation. Food fortification and supplementation: technological, safety and regulatory aspects. 2008, 1-10. Cambridge, UK: Woodhead Publishing. https://doi.org/10.1533/9781845694265.1

8. World Bank. World Development Report 1993: Investing in Health, Volume 1. The World Bank; 1993. https://doi.org/10.1080/08039410.1993.9665939

9. Hurrell R, Egli I. Iron bioavailability and dietary reference values. The American journal of clinical nutrition. 2010, 91(5):1461S-7S. https://doi.org/10.3945/ajcn.2010.28674F

10. Cardoso RVC, Fernandes Â, Gonzaléz-Paramás AM, Barros L, Ferreira IC. Flour fortification for nutritional and health improvement: A review. Food Research International. 2019, 1(125):108-576. https://doi.org/10.1016/j.foodres.2019.108576

11. Poniedziałek B, Perkowska K, Rzymski P. Food Fortification: What's in It for the Malnourished World? Vitamins and Minerals Biofortification of Edible Plants 2020, 27 https://doi.org/10.1002/9781119511144.ch2

12. Gumus CE, Gharibzahedi SM. Yogurts supplemented with lipid emulsions rich in omega-3 fatty acids: New insights into the fortification, microencapsulation, quality properties, and health-promoting effects. Trends in Food Science \& Technology 2021, 110:267-269 https://doi.org/10.1016/j.tifs.2021.02.016

13. Saltzman A, Birol E, Oparinde A, Andersson MS, AsareMarfo D, Diressie MT, Gonzalez C, Lividini K, Moursi M, 
Zeller M. Availability, production, and consumption of crops biofortified by plant breeding: current evidence and future potential. Annals of the New York Academy of Sciences 2017, 1390(1):104-14.

https://doi.org/10.1111/nyas.13314

14. Liberal Â, Pinela J, Vívar-Quintana AM, Ferreira IC, Barros L. Fighting Iron-Deficiency Anemia: Innovations in Food Fortificants and Biofortification Strategies. Foods 2020, 9(12):1871. https://doi.org/10.3390/foods9121871

15. Szymandera-Buszka K, Waszkowiak K, Kaczmarek A, Zaremba A. Wheat dietary fibre and soy protein as new carriers of iodine compounds for food fortification-The effect of storage conditions on the stability of potassium iodide and potassium iodate. LWT 2021, 137:110424. https://doi.org/10.1016/j.lwt.2020.110424

16. Smoleń S, Ledwożyw-Smoleń I, Sady W. lodine biofortification of spinach by soil fertigation with additional application of humic and fulvic acids. New Zealand Journal of Crop and Horticultural Science 2017, 45(4):233-50.

https://doi.org/10.1080/01140671.2017.1314307

17. Doh HS, Ko JA, Park HJ. Preparation of Novel lodized Salt with Natural lodine-Rich Sources by Spray Drying. Journal of food science 2018, 83(6):1676-84. https://doi.org/10.1111/1750-3841.14163

18. Palacios C, Cormick G, Hofmeyr GJ, Garcia-Casal MN, PeñaRosas JP, Betrán AP. Calcium-fortified foods in public health programs: considerations for implementation. Annals of the New York Academy of Sciences 2021, 1485(1):3. https://doi.org/10.1111/nyas.14495

19. Rafferty K, Walters G, Heaney RP. Calcium fortificants: overview and strategies for improving calcium nutriture of the US population. Journal of food science 2007, 72(9): R152-8.

https://doi.org/10.1111/j.1750-3841.2007.00521.x

20. Sharma N, Sharma S, Singh B, Kaur G. Stability evaluation of iron and vitamin A during processing and storage of fortified pasta. Quality Assurance and Safety of Crops \& Foods 2020, 12(2):50-60. https://doi.org/10.15586/qas.v12i2.656

21. Reddy GB, Pullakhandam R, Ghosh S, Boiroju NK, Tattari S, Laxmaiah $A$, at al. Vitamin A deficiency among children younger than $5 \mathrm{y}$ in India: an analysis of national data sets to reflect on the need for vitamin A supplementation. The American Journal of Clinical Nutrition 2021, 113(4):939 https://doi.org/10.1093/ ajcn/nqaa314
22. Mudgil D. Influence of partially hydrolyzed guar gum as soluble fiber on physicochemical, textural and sensory characteristics of yoghurt. Journal of Microbiology, Biotechnology and Food Sciences 2021, 2021:794-7. https://doi.org/10.15414/jmbfs.2018.8.2.794-797

23. Mudgil D, Barak S, Khatkar BS. Development and characterization of soluble fiber enriched noodles via fortification with partially hydrolyzed guar gum. Journal of Food Measurement and Characterization 2018, 12(1):15663. https://doi.org/10.1007/s11694-017-9626-y

24. Thøgersen R, Gray N, Kuhnle G, Van Hecke T, De Smet S, Young JF, et al. Inulin-fortification of a processed meat product attenuates formation of nitroso compounds in the gut of healthy rats. Food chemistry 2020, 302:125339. https://doi.org/10.1016/j.foodchem.2019.125339

25. Wessells, Hess. Zinc bioavailability from zinc-fortified foods. International journal for vitamin and nutrition research 2007, 77(3):174-81.

https://doi.org/10.1024/0300-9831.77.3.174

26. Hassan MU, Chattha MU, Ullah A, Khan I, Qadeer A, Aamer $M$, et al. Agronomic biofortification to improve productivity and grain $\mathrm{Zn}$ concentration of bread wheat. Int. J. Agric. Biol 2019, 21:615-20. https://doi.org/10.17957/IJAB/15.0936

27. M.S. Calvo, S.J. Whiting, Survey of current vitamin D food fortification practices in the United States and Canada, The Journal of Steroid Biochemistry and Molecular Biology, 2013, 136:211-213. https://doi.org/10.1016/j.jsbmb.2012.09.034.

28. Health Canada, Food and Drug Act B.09.016., 2018. [https://laws-

lois.justice.gc.ca/eng/regulations/C.R.C.,_c._870/sectionB.09.016.html] Retrieved Sep 16, 2021.

29. U.S.F.D.A. FDA, Food Additive Status List, [https://www.fda.gov/food/foodadditives-petitions/foodadditive-status-list] Retrieved Aug 26, 2021.

30. UK Gov, Red Tape Challenge, [https://webarchive.nationalarchives.gov.uk/ 20150507103822/http://www.redtapechallenge.cabineto ffice.gov.uk/about/] Retrieved May 07, 2015.

31. Grossman Z, Hadjipanayis A, Stiris T, Del Torso S, Mercier JC, Valiulis A, Shamir R. Vitamin D in European childrenstatement from the European Academy of Paediatrics (EAP). European journal of paediatrics 2017, 176(6):82931.

https://doi.org/10.1007/s00431-017-2903-2 
32. Saggese G, Vierucci F, Prodam F, Cardinale F, Cetin I, Chiappini $E$, et al. Vitamin $D$ in pediatric age: consensus of the Italian Pediatric Society and the Italian Society of Preventive and Social Pediatrics, jointly with the Italian Federation of Pediatricians. Italian journal of pediatrics 2018, 44(1):1-40.

https://doi.org/10.1186/s13052-018-0488-7

33. Verkaik-Kloosterman J, Seves SM, Ocké MC. Vitamin D concentrations in fortified foods and dietary supplements intended for infants: Implications for vitamin $D$ intake. Food Chemistry 2017, 221:629-35. https://doi.org/10.1016/j.foodchem.2016.11.128

34. P.R. Pehrsson, K.Y. Patterson, M.A. Khan, Selected vitamins, minerals and fatty acids in infant formulas in the United States, Journal of Food Composition and Analysis. 2014, 36: 66-71.

https://doi.org/10.1016/j.jfca.2014.06.004.

35. Holick MF. The vitamin D deficiency pandemic: approaches for diagnosis, treatment and prevention. Rev Endocrine Metab Disord 2017, 18:153-65. https://doi.org/10.1007/s11154-017-9424-1

36. Bouillon R, Marcocci C, Carmeliet G, Bikle D, White JH, Dawson-Hughes B. Skeletal and extra skeletal actions of vitamin D: current evidence and outstanding questions. Endocrine Rev 2019, 40:1109-51. https://doi.org/10.1210/er.2018-00126

37. Dankers W, Colin EM, van Hamburg JP, Lubberts E. Vitamin $D$ in auto immunity: molecular mechanisms and therapeutic potential. Front Immunol 2017, 7:697. https://doi.org/10.3389/fimmu.2016.00697

38. Infante M, Ricordi C, Sanchez J, Clare-Salzler MJ, Padilla N, Fuenmayor V. Influence of vitamin D on islet autoimmunity and beta-cell function in type 1 diabetes. Nutrients 2019, 11:2185. https://doi.org/10.3390/nu11092185

39. Greiller $\mathrm{CL}$, Martineau AR. Modulation of the immune response to respiratory viruses by vitamin D. Nutrients 2015, 7:4240-70. https://doi.org/10.3390/nu7064240

40. Gombart AF, Borregaard N, Koeffler HP. Human cathelicidin antimicrobial peptide (CAMP) gene is a direct target of the vitamin D receptor and is strongly upregulated in myeloid cells by 1,25-dihydroxyvitamin D3. FASEBJ 2005, 19:1067-77. https://doi.org/10.1096/fj.043284com

41. Ginde AA, Mansbach JM, Camargo CA. Association between serum 25-hydroxyvitamin $D$ level and upper respiratory tract infection in the Third National Health and
Nutrition Examination Survey. Arch Intern Med 2009, 169:384-90.

https://doi.org/10.1001/archinternmed.2008.560

42. Cannell JJ, Vieth R, Willett W, Zasloff $M$, Hathcock JN, White $\mathrm{JH}$, et al. Cod liver oil, vitamin A toxicity, frequent respiratory infections, and the vitamin $D$ deficiency epidemic. Ann Otol Rhinol Laryngol 2008, 117:864-70. https://doi.org/10.1177/000348940811701112

43. Grant WB, Lahore H, McDonnell SL, Baggerly CA, French $\mathrm{CB}$, Aliano JL. Evidence that vitamin D supplementation could reduce risk of influenza and COVID-19 infections and deaths. Nutrients 2020, 12:988.

https://doi.org/10.3390/nu12040988

44. Watkins J. Preventing a covid-19 pandemic. British Medical Journal Publishing Group; 2020. https://doi.org/10.1136/bmj.m810

45. Zhou Y-F, Luo B-A, Qin L-L. The association between vitamin $D$ deficiency and community-acquired pneumonia: a meta-analysis of observational studies. Medicine 2019, 98. 10.1097/MD.0000000000017252

46. Daneshkhah A, Agrawal V, Eshein A, Subramanian H, Roy $H K$, Backman V. The possible role of vitamin $D$ in suppressing cytokine storm and associated mortality in COVID-19 patient. Infect Dis (except HIV/AIDS) 2020. http://dx.doi.org/10.1101/ 2020.04.08.20058578.

47. De Smet D, De Smet K, Herroelen P, Gryspeerdt S, Martens GA. Vitamin D deficiency as risk factor for severe COVID19: a convergence of two pandemics. Infect Dis (except HIV/AIDS) 2020, http://dx.doi.org/10.1101/2020.05.01.20079376.

48. Hastie CE, Mackay DF, Ho F, Celis-Morales CA, Katikireddi SV, Niedzwiedz CL. Vitamin D concentrations and COVID19 infection in UK Biobank. Diabet Metab Syndr: Clin Res Rev 2020,14:561-5.

https://doi.org/10.1016/j.dsx.2020.04.050

49. Ilie PC, Stefanescu S, Smith L. The role of vitamin D in the prevention of coronavirus disease 2019 infection and mortality. Aging Clin Exp Res 2020, http://dx.doi.org/10.1007/s40520-020-01570-8.

50. Raharusun P, Priambada S, Budiarti C, Agung E, Budi C. Patterns of COVID-19 mortality and vitamin D: an Indonesian study. SSRN J 2020, http://dx.doi.org/10.2139/ssrn.3585561.

51. Teymoori-Rad M, Shokri F, Salimi V, Marashi SM. The interplay between vitamin D and viral infections. Rev Med Virol 2019, 29:2032. https://doi.org/10.1002/rmv.2032 
52. Guo Y-R, Cao Q-D, Hong Z-S, Tan Y-Y, Chen S-D, Jin H-J, et al. The origin, transmission and clinical therapies on coronavirus disease 2019 (COVID-19) outbreak - an update on the status. Military Med Res 2020, 7:11. https://doi.org/10.1186/s40779-020-00240-0

53. Jakovac H. COVID-19 and vitamin D-is there a link and an opportunity for intervention? Am J Physiol Endocrinol Metab 2020, 318:589. https://doi.org/10.1152/ ajpendo.00138.2020

54. Xiao F, Tang M, Zheng X, Liu Y, Li X, Shan H. Evidence for gastrointestinal infection of SARS-CoV-2. Gastroenterology 2020.

\section{https://doi.org/10.1053/j.gastro.2020.02.055}

55. Munasinghe LL, Yuan Y, Willows ND, Faught EL, Ekwaru JP, Veugelers PJ. Vitamin D deficiency and sufficiency among Canadian children residing at high latitude following the revision of the RDA of vitamin D intake in 2010. British Journal of Nutrition. 2017, 117(3):457-65. https://doi.org/10.1017/S0007114517000320

56. Manson JE, Brannon PM, Rosen CJ, Taylor CL. Vitamin D deficiency-is there really a pandemic. N Engl J Med. 2016, 375(19):1817-20.

https://knowledgeconnection. mainehealth.org/mmc/20

57. Allen LH. New approaches for designing and evaluating food fortification programs. The Journal of Nutrition. 2006,136(4):1055-8.

\section{https://doi.org/10.1093/jn/136.4.1055}

58. O'Mahony L, Stepien M, Gibney MJ, Nugent AP, Brennan L. The potential role of vitamin $D$ enhanced foods in improving vitamin D status. Nutrients. 2011, 3(12):102341.

https://doi.org/10.3390/nu3121023

59. Borel P, Caillaud D, Cano NJ. Vitamin D bioavailability: state of the art. Critical reviews in food science and nutrition. 2015, 55(9):1193-205. https://doi.org/10.1080/10408398.2012.688897

60. Hemery YM, Laillou A, Fontan L, Jallier V, Moench-Pfanner R, Berger J, Avallone S. Storage conditions and packaging greatly affects the stability of fortified wheat flour: Influence on vitamin A, iron, zinc, and oxidation. Food Chemistry. 2018, 240:43-50.

https://doi.org/10.1016/j.foodchem.2017.07.084

61. Pludowski P, Holick MF, Grant WB, Konstantynowicz J, Mascarenhas MR, Haq A, Povoroznyuk V, Balatska N, Barbosa AP, Karonova T, Rudenka E. Vitamin D supplementation guidelines. The Journal of steroid biochemistry and molecular biology. 2018, 175:125-35. https://doi.org/10.1016/j.jsbmb.2017.01.021

62. J. Jakobsen, P. Knuthsen, Stability of vitamin D in foodstuffs during cooking, Food chemistry, 2014, 148: 170-175. https://doi.org/10.1016/j.foodchem.2013.10.043.

63. O. Fennema, Chemical changes in food during processingan overview, Chemical changes in food during processing, Springer 1985, 1-16. https://doi.org/10.1007/978-1-4613$\underline{2265-8 \quad 1}$

64. K.D. Cashman, M. Kiely, Tackling inadequate vitamin D intakes within the population: fortification of dairy products with vitamin D may not be enough. Endocrine 2016, 51: 38-46.

https://doi.org/10.1007/s12020-015-0711-x

65. R. Kaushik, B. Sachdeva, S. Arora, B.K. Wadhwa, Development of an analytical protocol for the estimation of vitamin D2 in fortified toned milk. Food Chemistry 2014, 151: $225-230$.

https://doi.org/10.1016/j.foodchem.2013.11.085

66. D. Wagner, G. Sidhom, S.J. Whiting, D. Rousseau, R. Vieth, The bioavailability of vitamin $D$ from fortified cheeses and supplements is equivalent in adults, The Journal of Nutrition 2008, 138:1365-1371. https://doi.org/10.1093/in/138.7.1365.

67. B. Ganesan, C. Brothersen, D.J. McMahon, Fortification of Cheddar cheese with vitamin $D$ does not alter cheese flavor perception. Journal Of Dairy Science 2011, 94:3708-3714. https://doi.org/10.3168/jds.2010-4020

68. M. Tippetts, S. Martini, C. Brothersen, D. McMahon, Fortification of cheese with vitamin D3 using dairy protein emulsions as delivery systems, Journal of Dairy Science 2012, 95: 4768-4774.

https://doi.org/10.3168/jds.2011-5134.

69. R. Gupta, C. Behera, G. Paudwal, N. Rawat, A. Baldi, P.N. Gupta, Recent advances in formulation strategies for efficient delivery of vitamin D. AAPS Pharm Sci Tech 2009, 20 https://doi.org/10.1208/s12249-018-1231-9.

70. Chen, L., Remondetto, G.E., Subirade, M. Food proteinbased materials as nutraceutical delivery systems. Trends Food Sci. Technol. 2006, 17:272-283. https://doi.org/10.1016/j.tifs.2005.12.011

71. Ezhilarasi, P., Karthik, P., Chhanwal, N., Anandharamakrishnan, C. Nanoencapsulation techniques for food bioactive components: a review. Food Bioprocess Technol. 2013, 6: 628-647. https://doi.org/10.1007/s11947-012-0944-0 
72. Mozafari, M.R., Khosravi-Darani, K., Borazan, G.G., Cui, J., Pardakhty, A., Yurdugul, S. Encapsulation of food ingredients using nanoliposome technology. Int. J. Food Prop 2008, 11: 833-844. https://doi.org/10.1080/10942910701648115

73. Fathi, M., Martin, A., McClements, D.J. Nanoencapsulation of food ingredients using carbohydrate-based delivery systems. Trends Food Sci. Technol. 2014, 39:18-39. https://doi.org/10.1016/j.tifs.2014.06.007

74. Kreuter, J. Nanoparticles - a historical perspective. Int. J. Pharm. 2007, 331: 1-10. https://doi.org/10.1016/j.ijpharm.2006.10.021

75. Simi, C., Abraham, T.E. Hydrophobic grafted and crosslinked starch nanoparticles for drug delivery. Bioprocess Biosyst. Eng. 2007, 30:173-180. https://doi.org/10.1007/s00449-007-0112-5

76. Singh, R., Lillard Jr., J.W. Nanoparticle-based targeted drug delivery. Exp. Mol. Pathol. 2009, 86:215-223. https://doi.org/10.1016/j.yexmp.2008.12.004

77. Hancock, R.D., Tarbet, B.J. The other double helix - the fascinating chemistry of starch. J. Chem. Educ. 2000, 77: 988. https://doi.org/10.1021/ed077p988

78. Davis, J.P., Supatcharee, N., Khandelwal, R.L., Chibbar, R.N. Synthesis of novel starches in planta: opportunities and challenges. Starke 2003, 55:107-120. https://doi.org/10.1002/ star.200390036

79. Eliasson, A.-C., Krog. N. Physical properties of amylosemonoglyceride complexes. J. Cereal Sci. 1985, 3:239-248. https://doi.org/10.1016/S0733-5210(85)80017-5

80. Raphaelides, S., Karkalas, J. Thermal dissociation of amylose-fatty acid complexes. Carbohydr. Res. 1988, 172:65-82.

\section{https://doi.org/10.1016/S0008-6215(00)90843-7}

81. Biliaderis, C.G., Galloway, G. Crystallization behavior of amylose-V complexes: structure-property relationships. Carbohydr. Res. 1989, 189:31-48. https://doi.org/10.1016/0008-6215(89)84084-4

82. Tufvesson, F., Wahlgren, M., Eliasson, A.C. Formation of amylose-lipid complexes and effects of temperature treatment. Part 1. Monoglycerides. Starke 2003, 55:61-71. https://doi.org/ 10.1002/star.200390018

83. Kawada, J., Marchessault, R.H. Solid state NMR and X-ray studies on amylose complexes with small organic molecules. Starke 2004, 56:13-19. https://doi.org/ $\underline{10.1002 / \text { star. } 200300222}$
84. Cui, S.W. Food Carbohydrates: Chemistry, Physical Properties, and Applications. CRC Press. 2005.

85. Le Bail, P., Rondeau, C., Buleon, A. Structural investigation of amylose complexes with small ligands: helical conformation, crystalline structure and thermostability. Int. J. Biol. Macromol. 2005, 35: 1-7. https://doi.org/10.1016/j.ijbiomac.2004.09.001

86. Biais, B., Le Bail, P., Robert, P., Pontoire, B., Buleon, A. Structural and stoichiometric studies of complexes between aroma compounds and amylose. Polymorphic transitions and quantification in amorphous and crystalline areas. Carbohydr. Polym. 2006, 66:306-315. https://doi.org/10.1016/j.carbpol.2006.03.019

87. Fathima SJ, Nallamuthu I, Khanum F. Vitamins and minerals fortification using nanotechnology: bioavailability and Recommended Daily Allowances. In Nutrient Delivery 2017, 457-496. Academic Press. https://doi.org/10.1016/B978-0-12-804304-2.00012-3

88. Jafari SM. An overview of nanoencapsulation techniques and their classification. Nanoencapsulation technologies for the food and nutraceutical industries 2017, 1-34. https://doi.org/10.1016/B978-0-12-809436-5.00001-X

89. Akhavan S, Assadpour E, Katouzian I, Jafari SM. Lipid nano scale cargos for the protection and delivery of food bioactive ingredients and nutraceuticals. Trends in Food Science \& Technology 2018, 74:132-46. https://doi.org/10.1016/j.tifs.2018.02.001

90. Liu W, Ye A, Singh H. Progress in applications of liposomes in food systems. In Microencapsulation and microspheres for food applications 2015, 151-170. Academic Press. https://doi.org/10.1016/B978-0-12-800350-3.00025-X

91. K. Ziani, Y. Fang, D.J. McClements, Encapsulation of functional lipophilic components in surfactant-based colloidal delivery systems: vitamin $E$, vitamin $D$, and lemon oil, Food Chemistry 2012, 134:1106-1112. https://doi.org/10.1016/j.foodchem.2012.03.027

92. M. Haham, S. Ish-Shalom, M. Nodelman, I. Duek, E. Segal, M. Kustanovich, Y.D. Livney, Stability and bioavailability of vitamin $D$ nano encapsulated in casein micelles, Food \& Function 2012, 3:737-744. https://doi.org/10.1039/c2fo10249h

93. Maurya VK, Bashir K, Aggarwal M. Vitamin D microencapsulation and fortification: Trends and technologies. The Journal of Steroid Biochemistry and Molecular Biology. 2020, 1:196-105489. https://doi.org/10.1016/j.jsbmb.2019.105489 
94. Khan WA, Butt MS, Pasha I, Jamil A. Microencapsulation of vitamin $D$ in protein matrices: In vitro release and storage stability. Journal of Food Measurement and Characterization. 2020, 14(3): 1172-82. https://doi.org/10.1007/s11694-019-00366-3

95. I. Katouzian, S.M. Jafari, Nano-encapsulation as a promising approach for targeted delivery and controlled release of vitamins. Trends in Food Science \& Technology 2016, 53:34-48. https://doi.org/10.1016/j.tifs.2016.05.002

96. Y.L. Xie, H.M. Zhou, H.F. Qian, Effect of addition of peach gum on physicochemical properties of gelatin-based microcapsule. Journal of Food Biochemistry 2006, 30:302312. https://doi.org/10.1111/j.1745-4514.2006.00061.x

97. Y.L. Xie, H.M. Zhou, Z.R. Zhang, Effect of relative humidity on retention and stability of vitamin A microencapsulated by spray drying, Journal of Food Biochemistry 2007, 31:6880. https://doi.org/10.1111/j.1745-4514.2007.00099.x

98. N. Wilson, N. Shah, Microencapsulation of vitamins, ASEAN Food Journal 2007, 14:1. https://doi.org/10.1016/b978-012-404568-2.00038-8.

99. Y. Xie, A. WANg, Q. Lu, M. Hui, The effects of rheological properties of wall materials on morphology and particle size distribution of microcapsule, Czech Journal of Food Sciences 2010, 28:433-439. https://doi.org/10.17221/49/2009-cjfs

100. N. Schafroth, C. Arpagaus, U.Y. Jadhav, S. Makne, D. Douroumis, Nano and microparticle engineering of water insoluble drugs using a novel spray-drying process. Colloids and Surfaces B: Biointerfaces 2012, 90:8-15. https://doi.org/10.1016/j.colsurfb.2011.09.038

101. R. Murugesan, V. Orsat, Spray drying for the production of nutraceutical ingredients - a review. Food and Bioprocess Technology 2012, 5:3-14. https://doi.org/10.1007/s11947011-0638-z.

102. P. Ezhilarasi, P. Karthik, N. Chhanwal, C. Anandharamakrishnan, Nanoencapsulation techniques for food bioactive components: a review. Food and Bioprocess Technology 2013, 6:628-647. https://doi.org/10.1007/s11947-012-0944-0

103. A. Goncalves, B.N. Estevinho, F. Rocha, Microencapsulation of vitamin A: A review. Trends in Food Science \& Technology 2016, 51:76-87. https://doi.org/10.1016/j.tifs.2016.03.001

104. K.G.H. Desai, H. Jin Park, Recent developments in microencapsulation of food ingredients, Drying technology, $23 \quad$ (2005) 1361-1394.

https://doi.org/10.1081/drt-200063478

105. S.M. Loveday, H. Singh, Recent advances in technologies for vitamin A protection in foods. Trends In Food Science \& Technology 2008, 19:657-668. https://doi.org/10.1016/ j.tifs.2008.08.002.

106. A. Abbasi, Z. Emam-Djomeh, M.A.E. Mousavi, D. Davoodi, Stability of vitamin D3 encapsulated in nanoparticles of whey protein isolate. Food Chemistry 2014, 143:379- 383. https://doi.org/10.1016/j.foodchem.2013.08.018.

107. D. Danino, Y.D. Livney, O. Ramon, I. Portnoy, U. Cogan, Beta-casein assemblies for enrichment of food and beverages and methods of preparation thereof. Google Patents, 2014. https://doi.org/10.1021/jf060119c.

108. Y. Luo, Z. Teng, Q. Wang, Development of zein nanoparticles coated with carboxymethyl chitosan for encapsulation and controlled release of vitamin D3. Journal Of Agricultural and Food Chemistry 2012, 60:836843. https://doi.org/10.1021/jf204194z.

109. Z. Teng, Y. Luo, Q. Wang, Carboxymethyl chitosan-soy protein complex nanoparticles for the encapsulation and controlled release of vitamin D3. Food Chemistry 2013, 141:524 532

https://doi.org/10.1016/i.foodchem.2013.03.043.

110. Thuy PV, Berger J, Davidsson L, Khan NC, Lam NT, Cook JD, Hurrell RF, Khoi HH. Regular consumption of NaFeEDTAfortified fish sauce improves iron status and reduces the prevalence of anemia in anemic Vietnamese women. The American journal of clinical nutrition, 78(2):284-90. https://doi.org/10.1093/ajcn/78.2.284

111. Ranganathan S, Karmarkar MG, Krupadanam M, Brahmam GN, Rao MV, Vijayaraghavan K, Sivakumar B. Stability of iodine in salt fortified with iodine and iron. Food and nutrition bulletin 2007, 28(1):109-15. https://doi.org/10.1177/156482650702800112

112. De Valença AW, Bake A, Brouwer ID, Giller KE. Agronomic biofortification of crops to fight hidden hunger in subSaharan Africa. Global Food Security 2017, 12:8-14. https://doi.org/10.1016/j.gfs.2016.12.001

113. van Jaarsveld PJ, Faber $M$, Tanumihardjo SA, Nestel $P$, Lombard CJ, Benadé AJ. $\beta$-Carotene-rich, orange-fleshed sweet potato improves the vitamin A status of primary school children assessed with the modified-relative-doseresponse test. The American journal of clinical nutrition 2005, 81(5):1080-7. 
https://doi.org/10.1093/ajcn/81.5.1080

114. Haas JD, Beard JL, Murray-Kolb LE, Del Mundo AM, Felix A, Gregorio GB. Iron-biofortified rice improves the iron stores of nonanemic Filipino women. The Journal of nutrition 2005, 135(12):2823-30.

https://doi.org/10.1093/jn/135.12.2823

115. Masuda H, Aung MS, Nishizawa NK. Iron biofortification of rice using different transgenic approaches. Rice 2013, 6(1):1-2. https://doi.org/10.1186/1939-8433-6-40

116. Singh B, Goutam U, Kukreja S, Siddappa S, Sood S, Sharma J, Bhardwaj V. Biofortification Strategies to Improve Iron Concentrations in Potato Tubers: Lessons and Future Opportunities. Potato Research 2021, 1-4. https://doi.org/10.1007/s11540-021-09508-x

117. Beck SM, Knoerzer K, Foerster M, Mayo S, Philipp C, Arcot J. Low moisture extrusion of pea protein and pea fibre fortified rice starch blends. Journal of Food Engineering 2018, 231:61-71.

\section{https://doi.org/10.1016/j.jfoodeng.2018.03.004}

118. Zimmermann MB, Wegmueller R, Zeder C, Chaouki N, Biebinger R, Hurrell RF, Windhab E. Triple fortification of salt with microcapsules of iodine, iron, and vitamin $\mathrm{A}$. The American journal of clinical nutrition 2004, 80(5):1283-90. https://doi.org/10.1093/ajcn/80.5.1283

119. Jeyakumari A, Zynudheen AA, Parvathy $U$. Microencapsulation of bioactive food ingredients and controlled release-A review. MOJ Food process Technology 2016, 2(6): 1-9. https://doi.org/10.15406/mojfpt.2016.02.00059

120. Kumari A, Chauhan AK. Iron nanoparticles as a promising compound for food fortification in iron deficiency anemia: a review. Journal of Food Science and Technology 2021, 17. https://doi.org/10.1007/s13197-021-05184-4

121. Hosseini SF, Ramezanzade L, McClements DJ. Recent advances in nanoencapsulation of hydrophobic marine bioactives: Bioavailability, safety, and sensory attributes of nano-fortified functional foods. Trends in Food Science \& Technology 2021, 109:322-339. https://doi.org/10.1016/j.tifs.2021.01.045

122. Lindsay A, Bruno BD, Omar D and Richard H. Guidelines on food fortification with micronutrients. World Health Organization, Food and Agricultural Organization of the United Nations: Geneva, Switzerland 2006, 3-37. [https://www.who.int/nutrition/publications/micronutrie nts/guide_food_fortification_micronutrients.pdf]
123. S. Itkonen, M. Erkkola, C. Lamberg-Allardt, Vitamin D fortification of fluid milk products and their contribution to vitamin $D$ intake and vitamin $D$ status in observational studies - A review, Nutrients 2018, 10:1054 https://doi.org/10.3390/nu10081054.

124. Canadian Food Inspection Agency, Dairy Vitamin Addition, [http://www.inspection.gc.ca/food/requirementsandguid ance/labelling/industry/fortification/eng/1468504433692 [1468504697186] Retrieved Dec 17, 2019.

125. Health Canada. Canada, Food and Drug Regulations (C.R.C.,c.870),[https://laws.justice.gc.ca/eng/regulations/ c.r.c.,_c._870/index.html] Retrieved Sep 16, 2021

126. Australia New Zealand Food Standards Code, Australia New Zealand Food Standards Code- Standard 1.3.2 Vitamins and Minerals,

[https://www.legislation.gov.au/Details/F2017C00313]

127. Food and Agriculture Organization, Legislation pertaining to food fortification.

[http://www.fao.org/3/w2840e/w2840e0e.htm] Retrieved Oct 21, 2021.

128. FSSAI, Large scale food fortification in India: The Journey so Far and Road Ahead [https://archive.fssai.gov.in/dam/jcr:c746d723.../Large_sc ale Food Fortification.pdf] Published Oct, 2017.

129. C.P. Isabelle M., Wijaya S.Y. Report on Regulatory Status of Micronutrient Fortification in Southeast Asia [https://www.ign.org/cm data/ILSI SEA Region Report - Micronutrient Fortification Regulations.pdf] Published Dec, 2011.

130. Albert AP, Aleta CDB, Alma AB. Food and Drug Administration Philippines, Republic Act No. 8976, Philippine Food Fortification Act of 2000. [https://ap.fftc.org.tw/article/795] Published Dec 14, 2014.

131. M.S. Calvo, S.J. Whiting, C.N. Barton, Vitamin D fortification in the United States and Canada: current status and data needs, The American Journal of Clinical Nutrition 2004, 80:1710S-1716S. https://doi.org/10.1093/ajen/80.6.1710s 